
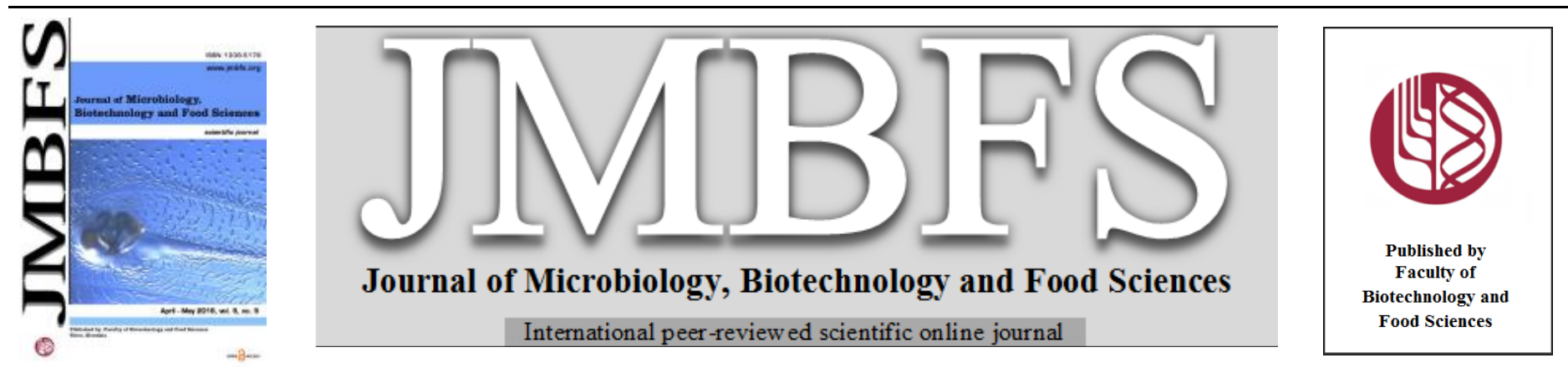

\title{
GENETIC DIVESITY AND EXTRACELULLAR ENZYMATIC ACTIVITY OF BACILLUS LICHENIFORMIS STRAINS FROM MILK POWDER
}

\author{
Marcela J. González*, Jorge A. Olivera, Jorge Bermúdez, Stella M. Reginensi \\ Address(es): MSc. Marcela J. González, \\ Unidad de Tecnología de los Alimentos, Facultad de Agronomía, Garzón 780, CP 12900, Montevideo, Uruguay, + 59823547991.
}

*Corresponding author: marcejoan@gmail.com

doi: 10.15414/jmbfs.2016.5.5.460-464

\section{ARTICLE INFO}

Received 4. 5. 2015

Revised 7. 12. 2015

Accepted 17. 12. 2015

Published 1. 4. 2016

Regular article OPEN $\partial_{\text {ACCESS }}$

\begin{abstract}
A total of 379 B. licheniformis strains isolated from commercial milk powder were characterized genotypically and phenotypically. RAPD analysis yielded three different profiles, which include all isolates in this study, which could be assigned to strain $\mathrm{F}$ ( $\mathrm{n}=375$ ) or strain $\mathrm{G}(\mathrm{n}=4)$ ), strain $\mathrm{F}$ also could be divided into two groups (group 1, $\mathrm{n}=117$; group $2, \mathrm{n}=258$ ). Clustering by pairwise sequence similarity and phylogenetic relationships between isolates based on comparisons of the 16S rRNA gene sequence, showed two well defined groups. Group I contains all isolates tested belonging to genotype F, and Group II consists of three G genotype isolates. A total of 32 isolates, respecting the representation of each genotype, were randomly selected for extracellular enzymatic activity plate assays. Most isolates (25 out of 32) showed extracellular proteinase, lipase and amylase activity. Hydrolytic activities tested in this study are strain-dependent and none enzymatic activity could be linked to a defined group at genetic level. Preliminar characterization of proteolytic crude enzyme extract suggests the presence of a metal-activated serine protease active at an optimun temperature of $60{ }^{\circ} \mathrm{C}$. The exoenzymes production and its variation against different factors such as temperature, is isolate dependent so these results indicate that not all B. licheniformis strains may mean the same risk to process or product quality.
\end{abstract}

\section{INTRODUCTION}

Spore-forming bacilli are common contaminants in dairy products and have been detected throughout the dairy processing, including dairy farm environments, storage and transportation tanks, and dairy processing plants (Crielly et al., 1994; Postollec et al., 2012). Spore-forming microorganisms enter processing plants from farm environments via milk, and in some cases multiplying within processing stages where conditions are suitable for bacterial growth. Thermal processes based on high temperatures are used in food industries to guarantee stability and safety of the products. However, these thermal treatments are no always sufficient to inactivate all spore-forming bacteria, especially those that are highly heat-resistant. In most cases spore-forming bacteria do not present safety concerns, however they can impact on spoilage and product specification requirements, as in the case of thermophilic bacilli contaminants in milk powders (Reginensi et al., 2011; Ronimus et al., 2003; Rueckert et al., 2004; Scott et al., 2007). The presence of the thermophilic bacilli in dairy products is indicator of poor hygiene and high counts are unacceptable, since they can lead to product defects caused by the production of heat-stable enzymes, such as proteinases and lipases, and acids capable to spoil the final product (Chopra and Mathur, 1984; Cosentino et al., 1997; Chen et al., 2004).

In a survey of milk powders from numerous countries, Bacillus licheniformis, Anoxybacillus flavithermus and Geobacillus spp. constituted $92 \%$ of sporeforming species isolated (Ronimus et al., 2003). B. licheniformis is a bacterium commonly found in nature, is the thermophilic bacilli most commonly isolated from raw milk (Crielly $\boldsymbol{e t}$ al., 1994) and has been described as one of the two predominant species in Uruguayan dairy powders (Reginensi $\boldsymbol{e t}$ al., 2011). It is a Gram positive rod-shaped spore-forming bacteria, mobile and facultative anaerobic. Belonging to $B$. subtilis group of the genus Bacillus, further comprising B. subtilis, B. amyloliquefaciens, B. pumilus, B. atrophaeus, B. mojavensis, $B$. sonorensis, $B$. vallismortis, $B$. firmus, $B$. lentus and $B$ sporothermodurans (Fritze, 2004). This organism is of great interest not only because of its predominance in the production line of milk powder but also for the broad technological potential of the bacterium itself and its extracellular products (Schallmey et al., 2004). Proteases are used in detergent and leather industry, while amylases are used in textile and paper manufacture (Priest, 1977). However, these enzymes can be a primary source of spoilage of milk and the manufactured dairy products. Intensive heat treatments (i.e. UHT) at dairy industry are able to lower the load of these microorganism, but exoenzymes may be thermostable (i.e. proteases and lipases) and only partially inactivated with further action on the product (Chen $\boldsymbol{e t}$ al., 2003). Several authors confirmed that bacterial proteinases and lipases found in milk survived all the heat treatments applied during the manufacture of milk powder (e.g., pasteurisation and spraydrying) (Celestino et al. 1997a,b; Chen et al., 2004), and these enzymes remained active in reconstituted milk even after a further 6 months storage at 25 ${ }^{\circ} \mathrm{C}$ (Celestino et al., 1997b).

Identification of the microorganisms that may be contributing to milk powder spoilage can help in implementing preventive and corrective actions, with an approach directed to find critical control points through the dairy chain Molecular methods able to rapidly detect and identify thermophilic contaminants are essential to improve the industrial response. B. licheniformis can be isolated from commercial milk powder under 'mesophile' and 'thermophile' growth conditions (Reginensi et al., 2011). Various methods, including multi-locus enzyme electrophoresis and phenotypic analysis (Duncan et al., 1994), random amplification of polymorphic DNA (RAPD) (Ronimus et al., 2003), rpoB and gyrA sequencing (De Clerck and De Vos, 2004), and bacitracin synthetase gene sequences (Ishihara et al., 2002) are currently used for genotyping $B$ licheniformis. Two or three different subgroups have been discriminated by this methods. Recently, a multi-locus variable number tandem repeat analysis (MLVA) method and combined with high resolution melt analysis (MLVHRMA) have been developed for genotyping B. licheniformis (Dhakal et al. 2013). Nineteen genotypes could be identified using this methodology, many of which are correlated with previously defined by RAPD-PCR (Ronimus et al., 2003).

In this study, we evaluated genotypic and phenotypic biodiversity of $B$. licheniformis strains isolated from Uruguayan commercial milk powder, with emphasis on the production of extracellular enzymes. A better undestanding of the diversity will allow the validation of industrial process optimization to monitor and track $B$. licheniformis wild strains as an aid to minimize quality and safety problems for food processors. 


\section{MATERIAL AND METHODS}

\section{Bacterial isolates and culture conditions}

Three hundred and seventy nine bacteria identified as B. licheniformis isolated from commercial milk powder manufactured in Uruguay belonging to our laboratory collection were used in this study. Isolates were prepared from frozen stocks after growth and transfer twice in fresh Triptic Soy Broth (TSB, Oxoid Ltd., UK) at $37{ }^{\circ} \mathrm{C}$ for $24 \mathrm{~h}$ prior to growth at different temperatures on Plate Count Agar (PCA, Oxoid Ltd., UK). A 100-fold dilution of each overnight culture was plated in duplicate on PCA and incubated at $37^{\circ} \mathrm{C}$ or $55^{\circ} \mathrm{C}$ for $24-48$

\section{Isolation of total DNA}

Bacterial cell cultures were grown overnight in Tryptic Soy Broth (TSB, Oxoid Ltd., UK) and cells were harvested at $10,000 \mathrm{rpm}$ for $5 \mathrm{~min}$ in a Spectrafuge $7 \mathrm{M}$ tabletop centrifuge (Labnet International Inc., USA). Cell pellets were suspended in $200 \mu \mathrm{L}$ TE buffer $(10 \mathrm{mM}$ Tris- $\mathrm{HCl}, 1 \mathrm{mM}$ EDTA, pH 8.0). DNA was purified using a Genomic DNA purification kit (Fermentas International Inc. USA) following the manufacturer's instructions. Purified DNA was suspended in $40 \mu \mathrm{L}$ TE buffer and used as template in amplification reactions. DNA concentration was determined using a NanoDrop 2000 spectrophotometer (Thermo Scientific Incorporation, Wilmington, DE, USA).

\section{RAPD-PCR analysis}

Random amplification of polymorphic DNA (RAPD) analysis was carried out in $25 \mu \mathrm{L}$ reaction mixtures containing $1 \times$ Thermo buffer (Fermentas, USA), $2.5 \mathrm{mM}$ $\mathrm{MgCl}_{2}, 200 \mu \mathrm{M}$ of each dNTP (Fermentas, USA), 1U Taq polymerase (Fermentas, USA), $1 \mu \mathrm{M}$ primer OPR13 (5'-GGACGACAAG-3') and $20 \mathrm{ng}$ template DNA. PCR amplifications were done in a Corbett CG1-96 therma cycler with a palmtop computer interface (Corbett Research Ltd., Cambridge, UK). PCR cycling parameters included a denaturation step at $94{ }^{\circ} \mathrm{C}$ for $3 \mathrm{~min}$ and $45 \mathrm{~s} ; 35$ cycles each consisting of $94{ }^{\circ} \mathrm{C}$ for $15 \mathrm{~s}, 36{ }^{\circ} \mathrm{C}$ for $15 \mathrm{~s}$ and $72{ }^{\circ} \mathrm{C}$ for 2 min; and a final extension step at $72{ }^{\circ} \mathrm{C}$ for $4 \mathrm{~min}$. (Ronimus et al., 1997). Control reaction mixtures lacking template DNA were included with each analysis. RAPD-PCR reactions were electrophoresed on $1.8 \%$ agarose-gels using $0.5 \times$ TBE buffer (45 mM Tris, $45 \mathrm{mM}$ Boric acid, $1 \mathrm{mM}$ EDTA, $\mathrm{pH}=8.0$ ) as running buffer at $10 \mathrm{~V} / \mathrm{cm}$ for $1 \mathrm{~h}$, stained with GoodView Nucleic Acid Stain $5 \%(\mathrm{v} / \mathrm{v})$ (SBS Genetech Co. Ltd, China) and visualized and photographed on a UV transilluminator.

\section{Isolate identification by $16 \mathrm{~S}$ rDNA sequence analysis}

Several isolates having distinct OPR13 RAPD profiles were identified by $16 \mathrm{~S}$ rDNA sequence analysis. Twenty-five microliter reaction mixtures contained $1 \times$ Thermo buffer (Fermentas, USA), $2.5 \mathrm{mM} \mathrm{MgCl}_{2}, 200 \mu \mathrm{M}$ of each dNTP (Fermentas, USA), 1U Taq polymerase (Fermentas, USA), $0.2 \mathrm{mM}$ of each PCR primer (fD1 and rD1) and $20 \mathrm{ng}$ template DNA. Primers fD1 5'AGAGTTTGATCCTGGCTCAG-3' and rD1 5'-AAGGAGGTGATCCAGCC-3 were used to amplify a 1540 bp genome fragment with 16S rRNA gene sequences (Weisburg et al., 1991). PCRs were performed using an initial denaturation step at $94{ }^{\circ} \mathrm{C}$ for $7 \mathrm{~min}$, then 35 cycles of $94{ }^{\circ} \mathrm{C}$ for $1 \mathrm{~min}, 56^{\circ} \mathrm{C}$ for $1 \mathrm{~min}$ and $72{ }^{\circ} \mathrm{C}$ for $1 \mathrm{~min}$ and a final extension at $72{ }^{\circ} \mathrm{C}$ for $10 \mathrm{~min}$, and experiments included negative controls with no added DNA template. Amplified fragments were purified and sequenced by Macrogen Sequencing Service, Korea, using an ABI PRISM 3730XL capillary sequencer (Applied Biosystems, CA, USA). DNA sequences were compared with those of the NCBI BLAST database (http://blast.ncbi.nlm.nih.gov/Blast.cgi) to identify type strains with highes similarity, and were aligned against each other using Clustal W package (Thompson et al., 1994). Phylogenetic trees were constructed using neighbourjoining method (Saitou and Nei, 1987) by MEGA4 software (Tamura et al., 2007).

\section{Enzymatic activity}

From a total of 379 isolates of $B$. licheniformis genotypically characterized, a total of 32 isolates, respecting the representation of each genotype, were randomly selected for extracellular enzymatic activity. The proteolytic activity was tested by culturing the strains on $50 \%$ skim milk agar and incubating the plates at $37^{\circ} \mathrm{C}$ and $55^{\circ} \mathrm{C}$ for $24-48 \mathrm{~h}$. Presence of clear zone of hydrolysis around the colonies was taken as positive for proteolysis. The lipolytic activity was tested by culturing the strains in Spirit Blue agar supplemented with $30 \%$ of lipase reagent (Difco, Becton Dickinson and Company, Nevada, USA) and incubating the plates at $37^{\circ} \mathrm{C}$ for 3 days and screening the plates for the presence of clear zone of hydrolysis as described by Starr and Burkholder (1942). The amylolytic activity was tested by culturing the strains on PCA plates supplemented with $1 \%$ soluble starch (w/v, Difco) and incubating the plates a $37^{\circ} \mathrm{C}$ for $24-48 \mathrm{~h}$. Amylase activity was detected by flooding the plates with
Gram's iodine solution $\left(0.203 \mathrm{~g}\right.$ of $\mathrm{I}_{2}$ and $5.2 \mathrm{~g}$ of $\mathrm{KI}$ in $100 \mathrm{ml}$ of aqueous solution), active isolates were detected as bright clear haloes around the colonies.

\section{Preparation of crude enzyme}

All proteolytic isolates were cultivated in $250 \mathrm{ml}$ nutrient broth with vigorous shaking $(150 \mathrm{rpm})$ at $37^{\circ} \mathrm{C}$ for $30 \mathrm{~h}$. The culture was then centrifuged at 15,000 $\mathrm{rpm}$ for $30 \mathrm{~min}$ at $4^{\circ} \mathrm{C}$. The cell free culture supernatant was filtered using 0.22 $\mu \mathrm{m}$ membranes (Millipore, Bedford, MA, USA) and maintained at $-40{ }^{\circ} \mathrm{C}$ for subsequent experiments.

\section{Quantification of proteolytic activity}

Determination of the enzyme activity was performed using the azocasein method (Andrews and Asenjo, 1986). $250 \mu$ of the crude enzymes were incubated at 37 ${ }^{\circ} \mathrm{C}$ in $500 \mu \mathrm{l}$ mixture containing $1 \%$ azocasein and $0.5 \mathrm{M}$ tris-(hydroxymethyl) aminomethane (TRIS) buffer $\mathrm{pH} 7.5$ for $1 \mathrm{~h}$. To terminate the reaction, $0.5 \mathrm{ml}$ of $1.5 \mathrm{M}$ trichloroacetic acid (TCA) was added. All samples were allowed to stand for $15 \mathrm{~min}$ and the supernatant was collected after centrifugation $(10,000 \mathrm{rpm}$; $15 \mathrm{~min})$. Protelytic activity was determined by measuring the absorbance at 340 $\mathrm{nm}$. One unit of enzyme activity (U) was defined as the amount of cell-free supernatant required to increase one unit of absorbance at $340 \mathrm{~nm}$ in the assay conditions.

Effect of temperature on proteolytic activity and influence of protease inhibitors

The effect of temperature on enzyme activity was determined by carrying out the enzyme assay in a temperature range between $30-70{ }^{\circ} \mathrm{C}$ at $\mathrm{pH} 7.5$. Enzyme activity at each temperature was measured as described above. The effects of active site inhibitors on protease activity were studied using phenylmethylsulfonylfluoride (PMSF), iodoacetimidate and ethylene diamine tetra acetic acid (EDTA). To determine whether the activity of proteases could be affected, each inhibitor was added to the crude enzymes and incubated at $35^{\circ} \mathrm{C}$ for $20 \mathrm{~min}$. Protease activity was then measured using the azocasein method.

\section{RESULTS AND DISCUSSION}

\section{RAPD genotyping of Bacillus licheniformis strains.}

Three hundred and seventy nine B. licheniformis isolates were characterized genotypically. RAPD analysis of isolates yielded three different RAPD profiles, which include all isolates in this study (Fig. 1). All three profiles matched those described previously (Ronimus et al., 2003; Rüeckert et al., 2004; Reginensi et al., 2011), corresponding to strain $F(n=375)$, and strain $G(n=4)$, although strain F could be divided into two groups (group 1, $n=117$; group 2, $n=258$ ). A more detailed analysis of the RAPD patterns showed that almost all isolates identified as B. licheniformis belonged to these two groups. Both profiles corresponded to strain $\mathrm{F}$, but differed from each other by the presence of an additional band of approximately 650 bp in group 2 (Fig. 1, Lanes 3, 6, 7, 9,10) A third group within this species had a different RAPD profile corresponding to strain G (Fig. 1, Lanes 12 to 14), but this group had a small contribution to $B$. licheniformis contamination in the powdered milk samples (4 out of 379 isolates). Distribution of $B$. licheniformis isolates agreed with other reports in which isolates of strain $\mathrm{F}$ (groups 1 and 2) were the dominant isolates in milk powder from New Zealand and Australia (Ronimus et al., 2003, Dhakal et al., 2013) as well as in milk powders manufactured in other countries (Rüeckert et al., 2004) The regular occurrence of $B$. licheniformis in powdered milk samples is likely due to the widespread distribution as a frequent contaminant in the dairy environment, like feed concentrate (Scheldeman et al., 2005; Vaerewijck et al. 2001), feces (Scheldeman et al., 2005), soiling of the udder and teats (Waes, 1976) and raw milk (Scheldeman et al., 2005)

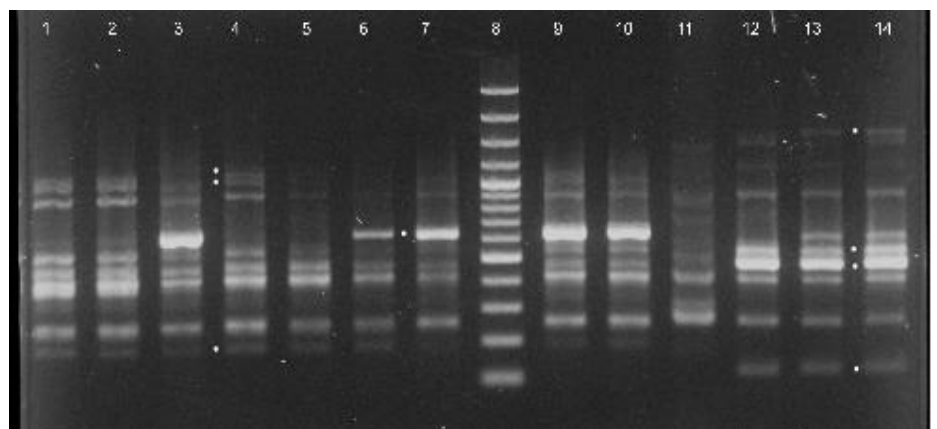

Figure 1 RAPD fingerprint profile of B. licheniformis isolates . Lanes 1, 2, 4, 5 and $11 \mathrm{~B}$. licheniformis $\mathrm{F}$ isolates subgroup 1; lanes 3, 6, 7, 9,10, B. licheniformis $\mathrm{F}$ isolates subgroup 2 with distinctive band at $650 \mathrm{bp}$; lanes $12-14 \mathrm{~B}$. lichenifomis G isolates; lane 8 DNA molecular mass standard ( (Generuler 100bp 
DNA Ladder Plus, Fermentas, bandas: 3000pb, 2000pb, 1500pb, 1200pb, $1000 \mathrm{pb}, 900 \mathrm{pb}, 800 \mathrm{pb}, 700 \mathrm{pb}, 600 \mathrm{pb}, 500 \mathrm{pb}, 400 \mathrm{pb}, 300 \mathrm{pb}, 200 \mathrm{pb}, 100 \mathrm{pb})$. *

Characteristics bands defined for each genotype are indicated.

Pairwise sequence similarity and phylogenetic relationships between isolates were inferred from comparisons of the $16 \mathrm{~S}$ rRNA gene sequence. Clustering into two groups well defined was observed (Fig. 2). Group I contains all isolates tested belonging to genotype F, and Group II consists of three $G$ genotype isolates. Ronimus et al. (2003) reference sequences of F (AY751766.1) and G (AY672764.1) isolates were also included and they appear clustered in group and II, respectively. Our results corresponded well with previous findings of two different lineages within $B$. licheniformis that seem to have evolved differently (De Clerck and De Vos, 2004, Madslien et al., 2012). Several techniques were used to study the genotypic diversity among isolates of $B$. licheniformis from different sources. On the basis of different DNA fingerprinting methods two major groups were determined (De Clerck and De Vos, 2004, De Jonghe et al. 2008, Banyko and Vyletelova, 2009), as well as by gyrA, rpoB and bac sequence analysis (De Clerck and De Vos, 2004, Ishihara et al., 2002). A recen analysis of diversity within the species $B$. licheniformis typing was performed by multilocus isolates sequences food contaminants. The evolutionary relationship inferred by the analysis of six "house keeping " genes, showed the presence of two groups or lineages (major one from the other) that appear to have evolved separately (Madslien et al., 2012).

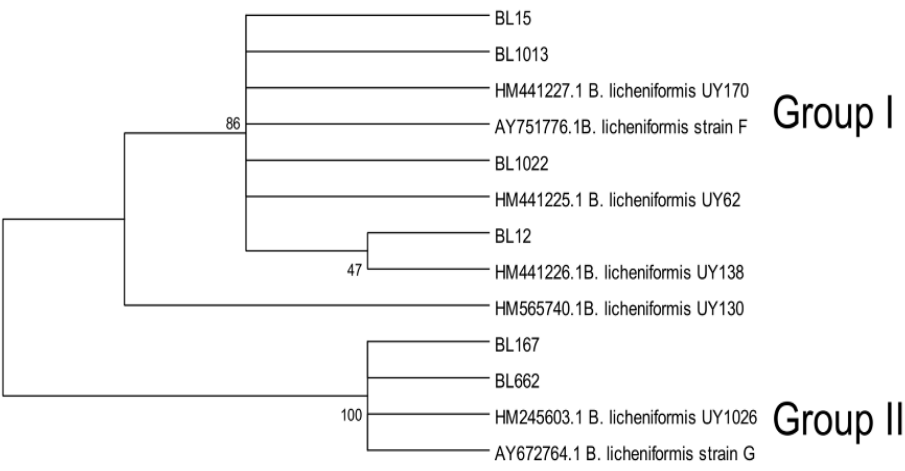

Figure 2 Phylogenetic tree obtained by Neighbor-joining analysis based on 16S rRNA gene sequences showing the phylogenetic position of isolates and type strains. Bootstrap values expressed as percentages of 1000 replications are shown at the branch points.

\section{Extracellular enzymatic activity}

A total of 32 isolates, respecting the representation of each genotype, were randomly selected for extracellular enzymatic activity plate assays. Bacillus species generally synthesise several extracellular enzymes, the maximum synthesis of which normally occurs in the late exponential and early stationary phases of growth, before sporulation (Priest, 1977). The results showed the ability of $B$. licheniformis isolates to produce exoenzymes with differen hydrolytic activities (Table 1). Most isolates (25 out of 32) were screened as capable of degrading casein, starch and lipids. All the 32 tested isolates showed lipolytic activity, 26 isolates were able to hydrolyze starch, while the ability to hydrolyze casein was found in 30 and 31 isolates when incubation temperature were 37 and $55{ }^{\circ} \mathrm{C}$, respectively (Table 1 ). None hydrolytic activity could be linked to a defined genetic group. Hydrolytic activities tested in this study were strain-dependent and proteolytic activity could eventualy (1 out of 31 isolates) be temperature dependent. This is an important fact to consider in the context of milk processing, and not all $B$. licheniformis strains represent the same risk to process or product quality.

Table 1 Qualitative assessment of extracellular enzymatic activity of $B$. licheniformis isolates.

\begin{tabular}{lcccc}
\hline \multirow{2}{*}{ Isolates } & \multicolumn{2}{c}{ Proteolytic isolates } & $\begin{array}{c}\text { Amylolytic } \\
\text { isolates }\end{array}$ & $\begin{array}{c}\text { Lipolytic } \\
\text { isolates }\end{array}$ \\
\cline { 2 - 5 } & $37{ }^{\circ} \mathrm{C}$ & $55^{\circ} \mathrm{C}$ & $37{ }^{\circ} \mathrm{C}$ & $37{ }^{\circ} \mathrm{C}$ \\
\hline Strain F group 1 & $14 / 14$ & $14 / 14$ & $9 / 14$ & $14 / 14$ \\
Strain F group 2 & $13 / 14$ & $14 / 14$ & $14 / 14$ & $14 / 14$ \\
Strain G & $3 / 4$ & $3 / 4$ & $3 / 4$ & $4 / 4$ \\
\hline
\end{tabular}

All B. licheniformis strains that exhibited a clear zone around their colonies on skim milk agar were grown on nutrient broth for 30 hours and tested for proteolytic activity by the azocasein assay. As well as other Bacillus species, production of protease by this $B$. licheniformis is dependent on cell growth, reaching the maximum yield at early stationary phase (Olajuyigbe and Ajele, 2008). In the crude enzyme caseinolytic protease activity assay, no significan difference $(\mathrm{P}>0.05)$ among genotypic groups $\mathrm{F}$ and $\mathrm{G}$ was observed, but different levels of proteolytic activity were expressed by particular bacterial isolates (Fig 3). BL1026 and BL27 showed highest proteolytic activity amongst all $B$. licheniformis isolates tested (Fig. 3). Consequently, these isolates were selected for further studies.

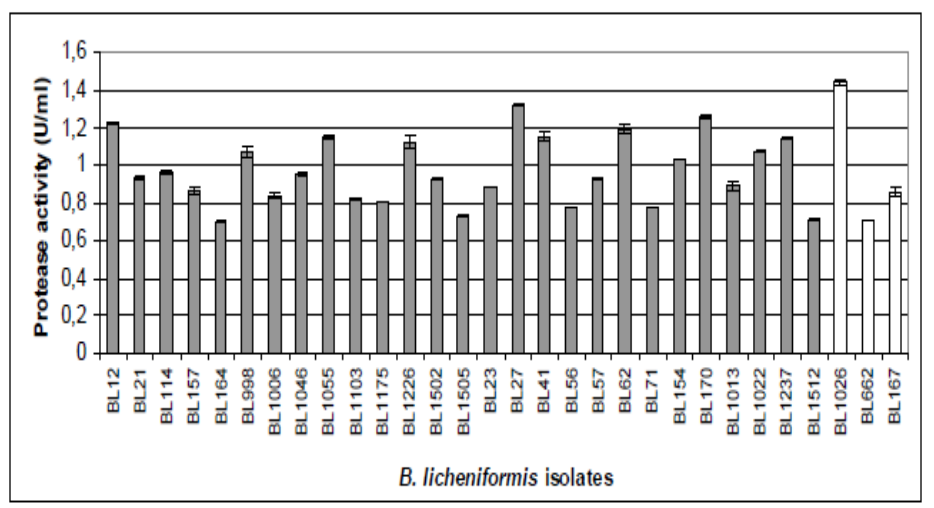

Figure 3 Proteolytic activity of $B$. licheniformis strain F ( $\square$ ) and strain G ( $\square$ ) isolates performed using azocasein method (Andrews and Asenjo, 1986) Experiments were performed in triplicate, and error bars indicate \pm SD.

\section{Effect of temperature and inhibitors on protease activity}

Proteases produced by mesophilic and thermophilic bacteria have been reported to be heat stable. The effect of temperature on protease activity was determined for isolates BL1026 and BL27 at temperatures between 30 and $70{ }^{\circ} \mathrm{C}$. Temperature profiles on enzyme activity are shown in Figure 4. Optimum temperature for the enzyme was found to be $60{ }^{\circ} \mathrm{C}$ for both isolates. Similar results were reported by other researchers where optimum temperature of $60^{\circ} \mathrm{C}$ was recorded for proteases from other B. licheniformis strains (Öztürk et al.,2009; Bezawada et al., 2011; El Hadj-Ali et al., 2007)

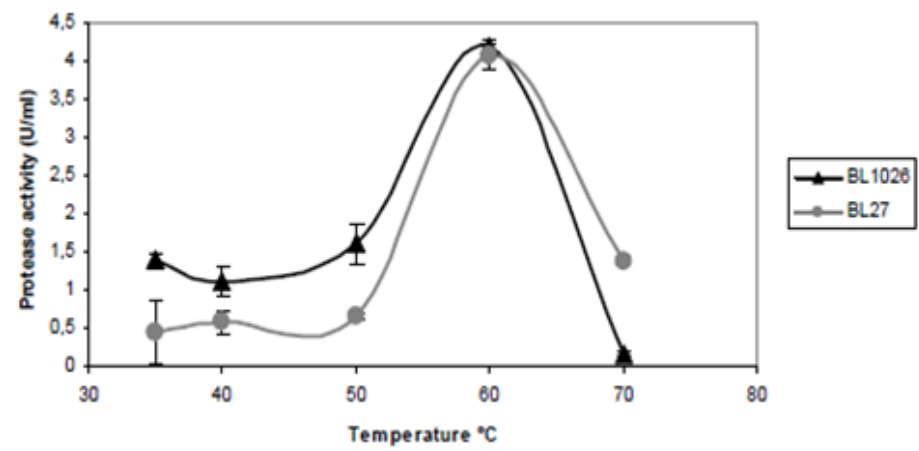

Figure 4 Effect of temperature on protease activity produced from $B$ licheniformis strains BL1026 and BL27. Experiments were performed in triplicate, and error bars indicate $\pm \mathrm{SD}$.

Inhibition studies primarily give an insight of the nature of an enzyme. The effect of a variety of enzyme inhibitors, such as chelating agent and group-specific reagent, on the activity was investigated (Table 2 ). The enzymes were strongly inhibited by the serine protease inhibitor (PMSF), indicating that both isolates produced serine proteases. Furthermore, the enzymes were equally affected when preincubated with EDTA, a metalloprotease inhibitor. Partial inhibition of many serine porteases by chelating agents has been reported (El Hadj-Ali et al., 2007, Fakhfakh et al., 2009) indicating the probable interaction of ions on the stabilization or activation of conformational structure of enzymes. These data indicate that the preparations contains a metal-activated enzyme with a serine residue at the active site. 
Table 2 Effect of inhibitors on activity of protease crude enzyme extract obtained from B. licheniformis strains BL1026 and BL27.

Relative activity in the presence of ${ }^{\text {a }}$

\begin{tabular}{lcccc} 
Strain & $\begin{array}{c}\text { No } \\
\text { inhibitors }\end{array}$ & 1 mM PMSF & 1 mM EDTA & $\begin{array}{c}\text { 0,1 mM } \\
\text { Iodoacetamide }\end{array}$ \\
\hline BL1026 & 100 & $25 \pm 3,4$ & $24 \pm 6,9$ & $98 \pm 0,4$ \\
BL27 & 100 & $19 \pm 3,7$ & $17 \pm 1,7$ & $99 \pm 6,0$ \\
\hline
\end{tabular}

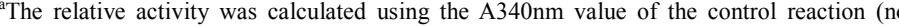
inhibitors) as $100 \%$ enzyme activity. Experiments were performed in triplicate and SD is indicated.

Many commercial proteases (Protemex ${ }^{\circledR}$, Neutrase ${ }^{\circledR}$ ), mainly neutral or alkaline are produced by microorganisms belonging to the genus Bacillus. Most of these proteases have been cloned and characterized. These enzymes were characterized as serine proteases, cysteine proteases or metalloproteases. Only a protease of this genus was characterized as atypical aspartic protease described in $B$ licheniformis (Carroll and Setlow, 2005). Generally, Bacillus species have higher extracellular and intracellular proteolytic activity than other bacteria and they commonly produce subtilases, members of the superfamily of subtilisin-like serine proteinases (Siezen and Leunissen, 1997). These enzymes are active at neutral or alkaline $\mathrm{pH}$. Many peptidases of this family are thermostable and the typical substrate for these enzymes is casein. Indications are that proteases produced by $B$. licheniformis isolates belong to this family but needed more comprehensive characterization.

\section{CONCLUSION}

These results confirm the diversity at genetic and phenotypic level of $B$ licheniformis isolated from milk powder. Up to now, it seems difficult to link a phenotypic characteristics to a defined group at genetic level. The study highligths the existence of groups with similar behaviors or characteritics but other strains with higher differences. The results of this work show that the exoenzymes production and its behaviour at different temperature tends to be isolate dependent. Further studies must be developed to determine the impact of enzyme activity and the number of microorganisms in the quality of dairy products.

\section{REFERENCES}

Andrews, B. A., \& Asenjo, J. A. (1986). Synthesis and regulation of extracellular $\beta$ (1-3) glucanase and protease by Cytophaga sp. in batch and continuous culture. Biotechnology and bioengineering, 28(9), 1366-1375. http://dx.doi.org/10.1002/bit.260280911

Bezawada, J., Yan, S., John, R. P., Tyagi, R. D., \& Surampalli, R. Y. (2011). Recovery of Bacillus licheniformis alkaline protease from supernatant of fermented wastewater sludge using ultrafiltration and its characterization.Biotechnology research international, 2011 http://dx.doi.org/10.4061/2011/238549

Banykó, J., \& Vyletělová, M. (2009). Determining the source of Bacillus cereus and Bacillus licheniformis isolated from raw milk, pasteurized milk and

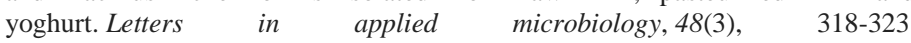
http://dx.doi.org/10.1111/j.1472-765X.2008.02526.x

Carroll, T. M., \& Setlow, P. (2005). Site-directed mutagenesis and structural studies suggest that the germination protease, GPR, in spores of Bacillus species is an atypical aspartic acid protease. Journal of bacteriology,187(20), 7119-7125. http://dx.doi.org/10.1128/jb.187.20.7119-7125.2005

Celestino, E. L., Iyer, M., \& Roginski, H. (1997a). The effects of refrigerated storage of raw milk on the quality of whole milk powder stored for different periods. International Dairy Journal, 7(2),

119-127. http://dx.doi.org/10.1016/s0958-6946(96)00041-6

Celestino, E. L., Iyer, M., \& Roginski, H. (1997b). Reconstituted UHT-treated milk: Effects of raw milk, powder quality and storage conditions of UHT milk on its physico-hemical attributes and flavour. International Dairy Journal,7(2), 129140. http://dx.doi.org/10.1016/s0958-6946(96)00042-8

Chen, L. D. R. M., Daniel, R. M., \& Coolbear, T. (2003). Detection and impact of protease and lipase activities in milk and milk powders.International dairy journal, 13(4), 255-275. http://dx.doi.org/10.1016/s0958-6946(02)00171-1

Chen, L., Coolbear, T., \& Daniel, R. M. (2004). Characteristics of proteinases and lipases produced by seven Bacillus sp. isolated from milk powder production lines. International dairy journal, 14(6), 495-504 http://dx.doi.org/10.1016/j.idairyj.2003.10.006

Chopra, A. K., \& Mathur, D. K. (1984). Isolation, screening and characterization of thermophilic Bacillus species isolated from dairy products. Journal of Applied Bacteriology, 57(2), 263-271. $\quad$ http://dx.doi.org/10.1111/j.1365 2672.1984.tb01390.x

Cosentino, S., Mulargia, A. F., Pisano, B., Tuveri, P., \& Palmas, F. (1997) Incidence and biochemical characteristics of Bacillus flora in Sardinian dairy products. International journal of food microbiology,38(2), 235-238. http://dx.doi.org/10.1016/s0168-1605(97)00107-4

Crielly, E. M., Logan, N. A., \& Anderton, A. (1994). Studies on the Bacillus flora of milk and milk products. Journal of applied bacteriology, 77(3), 256-263 http://dx.doi.org/10.1111/j.1365-2672.1994.tb03072.x

De Clerck, E., \& De Vos, P. (2004). Genotypic diversity among Bacillus licheniformis strains from various sources. FEMS microbiology letters,231(1), 91-98. http://dx.doi.org/10.1016/s0378-1097(03)00935-2

De Jonghe, V., Coorevits, A., Vandroemme, J., Heyrman, J., Herman, L., De Vos, P., \& Heyndrickx, M. (2008). Intraspecific genotypic diversity of Bacillus species from raw milk. International dairy journal, 18(5), 496-505. http://dx.doi.org/10.1016/j.idairyj.2007.11.007

Dhakal, R., Chauhan, K., Seale, R. B., Deeth, H. C., Pillidge, C. J., Powell, I. B. ... \& Turner, M. S. (2013). Genotyping of dairy Bacillus licheniformis isolates by high resolution melt analysis of multiple variable number tandem repeat loci. Food microbiology, 34(2),

http://dx.doi.org/10.1016/j.fm.2013.01.006

Duncan, K. E., Ferguson, N., Kimura, K., Zhou, X., \& Istock, C. A. (1994). Finescale genetic and phenotypic structure in natural populations of Bacillus subtilis and Bacillus licheniformis: implications for bacterial evolution and speciation. Evolution, 2002-2025. http://dx.doi.org/10.2307/2410523

El Hadj-Ali, N., Agrebi, R., Ghorbel-Frikha, B., Sellami-Kamoun, A., Kanoun, S., \& Nasri, M. (2007). Biochemical and molecular characterization of a detergent stable alkaline serine-protease from a newly isolated Bacillus licheniformis NH1. Enzyme and Microbial Technology, 40(4), 515-523. http://dx.doi.org/10.1016/j.enzmictec.2006.05.007

Fakhfakh, N., Kanoun, S., Manni, L., \& Nasri, M. (2009). Production and biochemical and molecular characterization of a keratinolytic serine protease from chicken feather-degrading Bacillus licheniformis RPk. Canadian journal of microbiology, 55(4), 427-436. http://dx.doi.org/10.1139/w08-143

Fritze, D. (2004). Taxonomy of the genus Bacillus and related genera: the aerobic endospore-forming bacteria. Phytopathology, 94(11),

$1245-1248$

http://dx.doi.org/10.1094/phyto.2004.94.11.1245

Ishihara, H., Takoh, M., Nishibayashi, R., \& Sato, A. (2002). Distribution and variation of bacitracin synthetase gene sequences in laboratory stock strains of Bacillus licheniformis. Current microbiology, 45(1), 18-23 http://dx.doi.org/10.1007/s00284-001-0041-5

Madslien, E. H., Olsen, J. S., Granum, P. E., \& Blatny, J. M. (2012). Genotyping of B. licheniformis based on a novel multi-locus sequence typing (MLST) scheme. BMC microbiology, 12(1), 230. http://dx.doi.org/10.1186/1471-2180-12230

Olajuyigbe, F. M., \& Ajele, J. O. (2008). Some properties of extracellular protease from Bacillus licheniformis LBBL-11 isolated from "iru", a traditionally fermented African locust bean condiment. Global J Biotechno Biochem, 3(1), 42 46. http://dx.doi.org/10.1111/i.1745-4514.2010.00362.x

Öztürk, S., Özeren-Morgan, M., Dilgimen, A. S., Denizci, A. A., Arikan, B., \& Kazan, D. (2009). Alkaline serine protease from halotolerantBacillus licheniformis BA17. Annals of microbiology, 59(1), 83-90. http://dx.doi.org/10.1007/bf03175603

Postollec, F., Mathot, A. G., Bernard, M., Divanac'h, M. L., Pavan, S., \& Sohier, D. (2012). Tracking spore-forming bacteria in food: from natural biodiversity to selection by processes. International journal of food microbiology, 158(1), 18.http://dx.doi.org/10.1016/j.ijfoodmicro.2012.03.004

Priest, F. G. (1977). Extracellular enzyme synthesis in the genus Bacillus Bacteriological reviews, 41(3), 711.

Reginensi, S. M., Gonzalez, M. J., Olivera, J. A., Sosa, M., Juliano, P., \& Bermudez, J. (2011). RAPD-based screening for spore-forming bacterial populations in Uruguayan commercial powdered milk. International journal of food microbiology, 148(1),

41.http://dx.doi.org/10.1016/j.ijfoodmicro.2011.04.020

Ronimus, R. S., Parker, L. E., \& Morgan, H. W. (1997). The utilization of RAPD-PCR for identifying thermophilic and mesophilic Bacillus species.FEMS Microbiology Letters, 147(1), 75-79. http://dx.doi.org/10.1016/s03781097(96)00507-1

Ronimus, R. S., Parker, L. E., Turner, N., Poudel, S., Rückert, A., \& Morgan, H. W. (2003). A RAPD-based comparison of thermophilic bacilli from milk powders. International journal of food microbiology,85(1), 45-61. http://dx.doi.org/10.1016/s0168-1605(02)00480-4

Rückert, A., Ronimus, R. S., \& Morgan, H. W. (2004). A RAPD-based survey of thermophilic bacilli in milk powders from different countries.International journal of food microbiology, 96(3), 263-272. http://dx.doi.org/10.1016/j.ijfoodmicro.2004.03.020

Saitou, N., \& Nei, M. (1987). The neighbor-joining method: a new method for reconstructing phylogenetic trees. Molecular biology and evolution, 4(4), 406425

Schallmey, M., Singh, A., \& Ward, O. P. (2004). Developments in the use of Bacillus species for industrial production. Canadian journal of microbiology,50(1), 1-17. http://dx.doi.org/10.1139/w03-076

Scheldeman, P., Pil, A., Herman, L., De Vos, P., \& Heyndrickx, M. (2005) Incidence and diversity of potentially highly heat-resistant spores isolated at dairy 
farms. Applied and Environmental Microbiology,71(3), 1480-1494. http://dx.doi.org/10.1128/aem.71.3.1480-1494.2005

Scott, S. A., Brooks, J. D., Rakonjac, J., Walker, K. M., \& Flint, S. H. (2007). The formation of thermophilic spores during the manufacture of whole milk powder. International journal of dairy technology,60(2), 109-117. http://dx.doi.org/10.1111/j.1471-0307.2007.00309.x

Siezen, R. J., \& Leunissen, J. A. (1997). Subtilases: the superfamily of subtilisin - like serine proteases. Protein Science, 6(3), 501-523. http://dx.doi.org/10.1002/pro.5560060301

Starr, M. P., \& Burkholder, W. H. (1942). Lipolytic activity of phytopathogenic bacteria determined by means of spirit blue agar and its taxonomic significance. Phytopathology, 32, 598-604.

Tamura, K., Dudley, J., Nei, M., \& Kumar, S. (2007). MEGA4: molecular evolutionary genetics analysis (MEGA) software version 4.0. Molecular biology and evolution, 24(8), 1596-1599. http://dx.doi.org/10.1093/molbev/msm092

Thompson, J. D., Higgins, D. G., \& Gibson, T. J. (1994). CLUSTAL W: improving the sensitivity of progressive multiple sequence alignment through sequence weighting, position-specific gap penalties and weight matrix choice. Nucleic acids research, 22(22), 4673-4680. http://dx.doi.org/10.1093/nar/22.22.4673

Vaerewijck, M. J. M., De Vos, P., Lebbe, L., Scheldeman, P., Hoste, B., \& Heyndrickx, M. (2001). Occurrence of Bacillus sporothermodurans and other aerobic spore - forming species in feed concentrate for dairy cattle. Journal of applied microbiology, 91(6), 1074-1084. http://dx.doi.org/10.1046/j.13652672.2001.01477.x

Waes, G. (1976). Aerobic mesophilic spores in raw milk. Milchwissenschaft (Germany, FR).

Weisburg, W. G., Barns, S. M., Pelletier, D. A., \& Lane, D. J. (1991). 16S ribosomal DNA amplification for phylogenetic study. Journal of bacteriology, 173(2), 697-703. 